\title{
EXPERIMENTAL STUDY ON PROPERTIES OF RAMMED EARTH BLENDED WITH GGBS AND SILICA FLUME
}

\author{
S.Jayakumar ${ }^{1}$, J.Hemachander ${ }^{2}$, J.Mohamedshahul Hameedh ${ }^{3}$ \\ ${ }^{1}$ Professor and Head, Department of Civil Engineering, Sri Manakula Vinayagar Engineering College, \\ Puducherry - 605107 \\ ${ }^{2,3}$ IV Year Student, Department of Civil Engineering, Sri Manakula Vinayagar Engineering College, \\ Puducherry - 605107
}

\begin{abstract}
Rammed earth construction is technique which was widely practiced for long time in semi-arid regions. Slowly the practice went out off existence due to lack of strength and feasibility. We concentrated in increasing the strength and reduce the effect of dampness to make it economical and a eco-friendly type of construction. After trying out different materials as a admixture to the earth material, GGBs and Silica fumes where found to a good composite material and they resulted in a tremendous increase in the strength of the earth wall material.
\end{abstract}

Keywords: Rammed Earth, Cost Effective, Eco-Friendly, GGBS, Increased Strength

\section{INTRODUCTION}

The term 'rammed earth' is common because it represents both the construction process and the material for construction, the material is a composition of clay, gravel and sand. There are many ancient buildings which are still standing till present. Then slowly the practice and importants of it faded away. In India many small villages adapted this method for their dwelling place. "We try to incorporate the old method with much more stable strength". The modern persistence in rammed earth is concentrated in particular parts of the world, such as California and Western Australia (Hodsdon ; Easton), but there is interest in the UK, as evidenced by the recent production of a design guide (Walker et al.,).

There is need for some material test in lab as well as in the field for the better understanding of the material and the construction methodology. To date, rammed earth has been regarded as a structural material much like masonry or concrete, and rules for design have developed accordingly. Little knowledge is available on the analysis of rammed earth structures, and even less on the origins of the material's strength.

The compressive strength of the earth wall materials are studied [1] and the strength of it is increased with the help of adding some composite materials.

\section{PROJECT DEVELPOMENT}

The process and progress of our work is step by step one it is like a trail and error method. We made use of rammed earth that is available around the college campus. And according to the standards mention in the New Mexican code for rammed earth structures for the mixing proportions. We made some lab test with the collected sample materials to know clearly the properties of the materials.
The aim of soil stabilization is to increase the soil's resistance to destructive weather conditions in one or more of the following ways:

By cementing the particles of the soil together, leading to increased strength and cohesion.

By reducing the movements (shrinkage and swelling) of the soil when its moisture content varies due to weather conditions.

By making the soil waterproof or at least less permeable to moisture.

The test was carried out as it was given in the geotechnical branch 1) optimum moisture content test. 2)core cutter test. 3)drop test. 4)specific gravity of soil. 5) particle size analysis test. We used the following materials for the mixing purpose coirfibre, silica fumes, fly ash, GGBS, banana fibre, to check for the maximum strength and the maximum compressive strength is taken and the result is tabulated. The cubes are casted and the curing is done at room temperature which is more often a dry curing.

\section{MATERIALS AND METHODLOGY}

To show the properties of locally available natural soil and comparing it with properties of soil suitable for rammed earth construction as per published literature.

\section{Ground-Granulated Blast-Furnace Slag (GGBS Or GGBFS)}

GGBS is obtained by quenching molten iron slag (a byproduct of iron and steel-making) from a blast furnace in water or steam, to produce a glassy, granular product that is 
then dried and ground into a fine powder. The chemical properties of GGBS are given in table1.

Table1: Chemical Composition of GGBS

\begin{tabular}{|l|l|}
\hline Oxide's & GGBS Composition \\
\hline $\mathrm{CaO}$ & 41 \\
\hline $\mathrm{SiO}_{2}$ & 35 \\
\hline $\mathrm{Al} 0_{3}$ & 11 \\
\hline $\mathrm{Fe}_{2} \mathrm{O}_{3}$ & 1 \\
\hline Insoluble residue & 0.3 \\
\hline Relative density & 2.9 \\
\hline Bulk density, $\mathrm{kg} / \mathrm{m}^{3}$ & 1200 \\
\hline Colour & Off-white \\
\hline
\end{tabular}

GGBS is a by-product of steel manufacturing process, its use in concrete is recognized by LEED etc. as improving the sustainability of the project and will therefore add points towards LEED certification. In this respect, GGBS can also be used for superstructure in addition to the cases where the concrete is in contact with chlorides and sulfates. This is provided that the slower setting time for casting of the superstructure is justified.

It has a higher proportion of the strength-enhancing calcium silicate hydrates (CSH) than concrete made with Portland cement only, and a reduced content of free lime, which does not contribute to concrete strength.Therefore, we are using this slag to natural earth to increase the strength.

\section{SILICA FUMES}

Silica fume is a byproduct of producing silicon metal or ferrosilicon alloys. One of the most beneficial uses for silica fume is in concrete. Because of its chemical and physical properties, it is a very reactive pozzolana.

Chemical and Physical characteristics:

$\begin{array}{ll}\mathrm{Sio}_{2} \text { content } & 85-97 \% \\ \text { Surface area, } \mathrm{m}^{2} / \mathrm{kg} & 17000-30000 \\ \text { Pozzolonic activity with cement } & 120-210 \% \\ \text { Pozzolonic activity with lime } & 8.3-11.4(\mathrm{MPa})\end{array}$

Because of its extreme fineness and high silica content, silica fume is a very effective pozzolanic material.

Silica fume is an ultrafine material with spherical particles less than $1 \mu \mathrm{m}$ in diameter, the average being about 0.15 $\mu \mathrm{m}$. This makes it approximately 100 times smaller than the average cement particle. The bulk density of silica fume depends on the degree of densification in the silo and varies from 130 (un-densities) to $600 \mathrm{~kg} / \mathrm{m}^{3}$. The specific gravity of silica fume is generally in the range of 2.2 to 2.3 .

\section{Test conducted on samples}

The samples collected underwent the following test to know their properties, the test or made by codes in table2.[2]
Table 2: Test Procedures for Soil Properties

\begin{tabular}{|l|l|}
\hline Properties & Reference code \\
\hline Grain Size Analysis & IS 2720 (part 4) 1985 [6] \\
\hline Atterberg's Limits & IS 2720(Part 5) 1985[4] \\
\hline Standard Proctor Test & IS: 2720 (Part 7) 1985[4] \\
\hline Linear Shrinkage & IS:720 (Part 20)-1992[7] \\
\hline Free Swell & IS:720 (Part 40)-1977[7] \\
\hline Weathering Test (Spray Test) & IS:725 1982 [8] \\
\hline
\end{tabular}

The details of specific gravity are given in table 3 .

Table 3: Specific Gravity Test

\begin{tabular}{|l|l|l|}
\hline \multicolumn{3}{|c|}{ Table 3: Specific Gravity Test } \\
\hline Material & Soil & GGBS \\
\hline Specific gravity & 2.7 & 2.85 \\
\hline
\end{tabular}

\section{Mix Proportion Details}

The mix proportion where refered by[9].

s1. $100 \%$ soil

s2. Soil $+10 \%$ of GGBS $+10 \%$ of silica fumes $+10 \%$ of water by mass

s3. Soil $+15 \%$ of GGBS $+10 \%$ of water by mass

s4. Soil $+10 \%$ of silica fumes $+10 \%$ of water by mass

s5. Soil $+15 \%$ of silica fumes $+10 \%$ of water by mass

s6. Soil $+10 \%$ of GGBS $+10 \%$ of water by mass

\section{TESTING ON CUBE}

\section{Compressive Strength Test}

Metal moulds measuring100mmX100mmX100mm were used to cast the sample rammed earth cubes. A number of 3 cubes where casted for every proportion and the cubes are tested and the results are calculated according to the days of the cube casted(dry curing for rammed earth)

The testing of sample cubes and after the testing of the cube is shown in the following figure $1 \& 2$

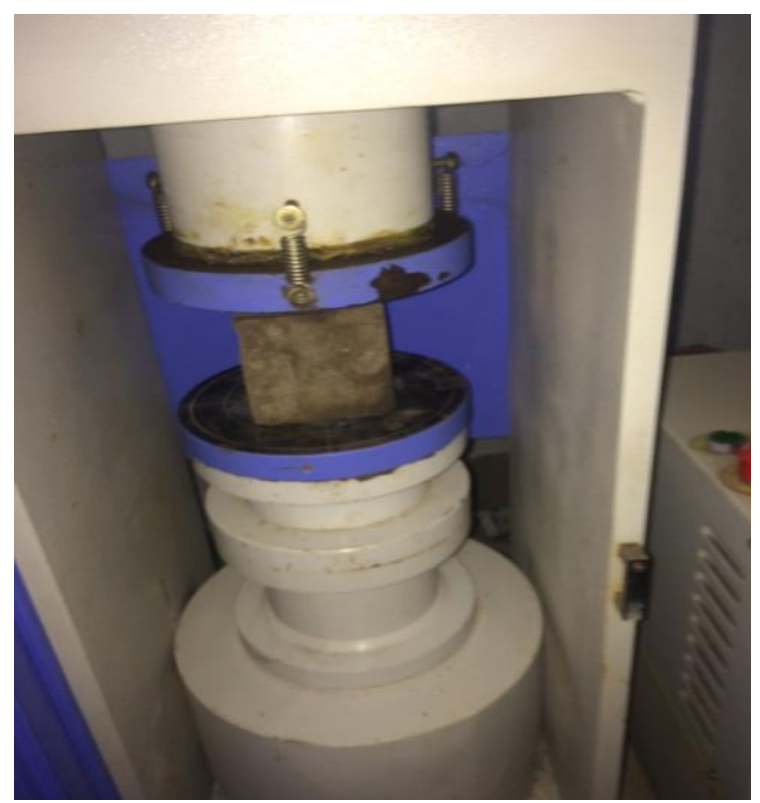

Fig 1. Compression test on sample cube 


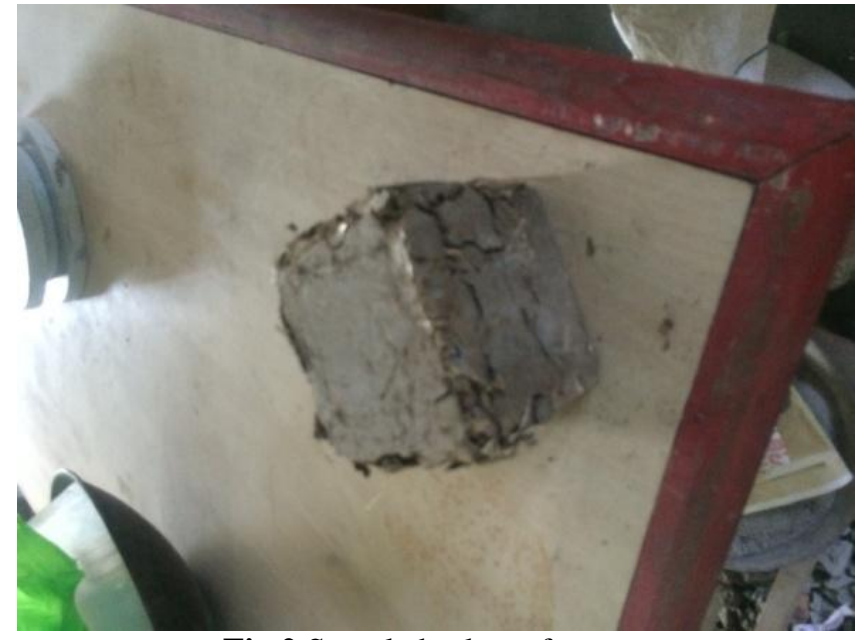

Fig 2 Sample broken after test

\section{RESULTS AND DISCUSSION}

\section{RESULTS}

After 7days of curing the results are given the following graph1,

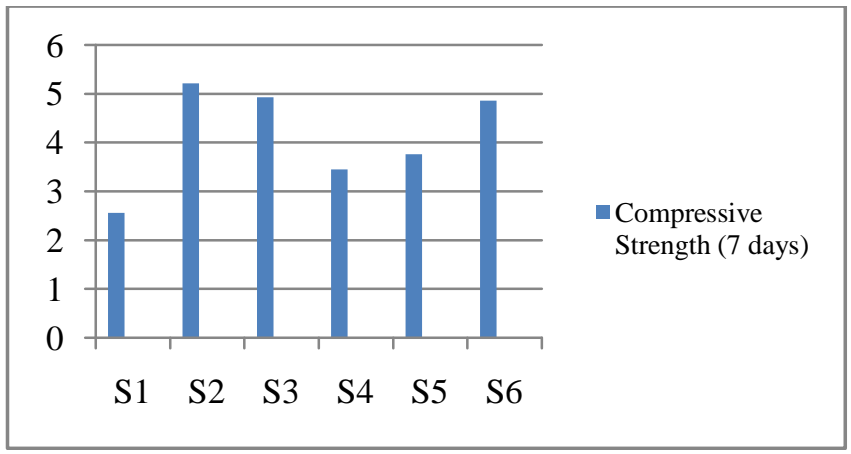

Graph 1 Compressive strength analysis

S1 $-2.56 \mathrm{Mpa}$ (standard strength)

$\mathrm{S} 2-5.21 \mathrm{Mpa}$

$\mathrm{S} 3-4.93 \mathrm{Mpa}$

$\mathrm{S} 4-3.45 \mathrm{Mpa}$

$\mathrm{S} 5-3.76 \mathrm{Mpa}$

$\mathrm{S} 6-4.86 \mathrm{Mpa}$

\section{DISCUSSION}

Compressive strength for the different cubes were taken and the result varied according to the mix proportion and the days of curing(dry). The mix of Soil $+10 \%$ of GGBS $+10 \%$ of silica fumes $+10 \%$ of water by mass gave the maximum result of $5.21 \mathrm{Mpa}$

\section{CONCLUSION}

The pre-existed methodology of the rammed earth construction was clearly portraying the economical and environmental advantage aspect. And the strength portion was not concentrated to the most. we concentrated on that part and we attained strength more than the pre-existing strength by the work we made towards the rammed earth field, the normal strength is $2.56 \mathrm{MPa}$ and we attained
5.21MPa by adding GGBS and silica fumes which is double that of the normal mix composition. Thus in future this method can be incorporated in the regions where the rammed earth construction is suitable since it is a cost efficient one.

\section{REFERENCE}

[1]. Prasanna Kumar P, "Stabilised Rammed Earth for Walls: Materials, Compressive Strength and Elastic Properties",Department of Civil Engineering. IISc, Bangalore, July 2009

[2]. IS 1498-1970, "Classification and Identification of soil for general engineering purpose".

[3]. IS 1725-1982, "Specification for soil based blocks used in general building construction".

[4]. IS 2720 (Part 10)-1991, "Method of Test for Soil (Determination of UCS)".

[5]. IS 2720 (Part 20)-1992, "Method of Test for Soil (Determination of Linear Shrinkage)".

[6]. IS 2720 (Part 4)-1985, "Method of Test for Soil (Grain Size Analysis)".

[7]. IS 2720 (Part 40)-1977, "Method of Test for Soil (Determination of Free Swell Index)".

[8]. IS 2720 (Part 5)-1985, "Method of Test for Soil (Determination of LL and PL)".

[9]. Hodsdon, T. (2006). Innovations in rammed earth construction, Western Australia. Structural Engineer 84, No. 10, 30-36. 